\title{
History of the Communist Party in Cyprus: Colonialism, Class and the Cypriot Left
}

Review Number: 1723

Publish date: Thursday, 5 February, 2015

Author: Yiannos Katsourides

ISBN: 9781780761749

Date of Publication: 2014

Price: $£ 60.00$

Pages: 256pp.

Publisher: I. B. Tauris

Publisher url: http://www.ibtauris.com/Books/Society\%20\%20social\%20sciences/Politics\%20\%20government/Pol 25EF-41FB-BE59-FC1C66CA2D57\%7D

Place of Publication: London

Reviewer: Alexios Alecou

Yiannos Katsouride's book on the history of the Communist Party of Cyprus (CPC) represents a comprehensive attempt to offer an analysis of the political and social realities on the island during an era commencing in 1922, shortly after the party was founded, and ending at the start of the 1940s when the its succesor was founded, the Progressive Party of Working People (AKEL: acronym of the Greek name). The founding of the CPC was the result of the developments and realities in Cyprus during the aforementioned era. As the writer noted aptly, although Cyprus' Left party has been considered as among Europe's most intriguing and unique parties, there hasn't been a lot of study on how the CPC emerged and what it did. Unlike other schemes of lower strata mobilisation, the CPC was a political movement with a specific programme for radical reform - in other words, it was politically conscious in its demands. It was an organised movement for social and political reform, not a spontaneous rising of the poorer strata. The establishment of the Party constituted a huge step forward in the founding members' efforts to avoid working class fragmentation and to establish the independence of the proletariat. Ever since, the CPC has represented lower class politics, building a distinct political culture based on a different value system. The Cypriot Left based its political identity on representation of the working class, solidarity with the Turkish Cypriots, and an anti-nationalistic, anti-imperialistic rhetoric. From this vantage point, the goal of writing the history of the $\mathrm{CPC}$ becomes difficult when referencing mostly primary sources.

Therefore it is inevitable that this study utilizes a number of primary sources, which while a positive asset also makes it hard to refute the author's conclusions. Primary sources include the archives of different countries, like England, Greece, and Cyprus, along with writings from the press of the party; secondary sources include party members' memoirs that have been published. What is of particular importance to this study is the author's approach to his sources, which is both analytical and interpretive. In addition to the extensive introduction and conclusions, the book is divided into seven key chapters. The author's framework is offered in the introduction to the book, where it is stated in detail that the work utilizes Lispet and Rokkan's class distinction categories and, by default, the Marxist outlook on issues of class and politics. From the introduction, it is clear that the author's approach is not one-dimensional. Instead, he attempts an approach that offers a documented and complete analysis of matters pertaining to how a political party in 
this period was created, especially in Cyprus.

The introduction and the first chapter make it clear that the issue was multi-dimensional, and the author attempts to provide a comprehensive and analytical documentation of what happened to allow the creation of a political party in Cyprus at that point. He examines the Cypriot's economic and societal pre-modern characteristics. Included in this are the island's conditions during the period of transition when the island came under the control of the British, and the transitional changes that occurred including organization in both a colonial and modern framework, the development of new economic actions, and primarily the apparent class distinctions of the bourgeoisie and the working class. The CPC entered the political arena claiming to represent only a part of the society and not the whole society - which is a characteristic of all mass parties. It succeeded in consolidating itself among the electorate, despite the limited influence suggested by its electoral percentages. The fact that the CPC's appearance coincided with the formation of the working class and the fact that the majority of its members were artisans and wage-labourers allowed the Party to acquire strong support among the most conscious section of this class and then extend its membership to the majority of the working class.

Moreover, the second chapter looks, in a methodical way, at the socio-economic conditions as they relate to what is required for a political formation to appear. At the same time, the author analyzes the new political framework that the colonial administration brought to the island with a particular focus on the characteristics of modernity, like the foundation of electoral procedures and representative institutions. This is especially true in cases where the colonial era's main representative body, the Legislative Council, was involved and held elections to select its members. Here, the author looks at social composition, where he observes how the lower classes were excluded from the political processes that were transpiring. What resulted was an oligarchic parliamentary system, where there was a huge chasm between those elected to the legislature and the rest of the population. Analyzing these facts allows a conclusion to be drawn that this was a clientelistic system, meaning that the elective process was used as a way to legalize the reality of colonialism.

The third chapter of the book analyzes the political process as it developed during the emergence of the CPC on the island. There is a recording of the first attempts to create political parties following an analysis of the most critical urban and rural mobilizations. By the mid 1920s, the first socialist groups had begun to appear, and the CPC was set up in 1926 after several of these had formed.

In the book's fourth chapter, the new party's trends are explored, and this also contains a thorough analysis of its ideology, while concentrating on various aspects of its political agenda. This party tried, through its actions, to serve as a representative for most of the lower social classes, so they could improve their lives. The portions that discuss the party's policy with regard to the Church of Cyprus and the request for Union (Enosis) are needed and very informative. The CPC contemplated the national question as a component of socio-political issues as they tried to introduce the concept of a common struggle to the Turkish-Cypriot community. Even though he doesn't analyze 'national' identity, as this may be deemed to be outside the scope of this study, there is sufficient work done on the CPC's attitude toward the recently set up 'national matter'. The party critiqued the way the Church joined with the upper classes to exploit the lower classes, while trying to give back church land to the farmers, and this may have been the first time that the church was criticized in this way. There might be better awareness of how the CPC reacted if a closer look had been taken at how the church operated as an authoritarian structure with specific economic power during the Ottoman and colonial periods. 
Chapter five analyses the methods and structures of Party organisation, both in relation to society and internally. In this respect, the concept of the 'parallel society' is introduced and a number of issues are examined: party press, internal structure, members and leadership, relations with the trade unions and with other communist centres abroad. Essentially, the chapter discusses the various 'repertoires of working class mobilisation' that the communists employed. The author examines the forms and tactics the Party used in the effort to organise the working and agrarian classes: the establishment of working centres, and trade unions and strikes.

The book's sixth chapter looks at the party's organizational structure and what its members and staff did to improve access to both Greek-Cypriot and Turkish-Cypriot society. The author's extensive analysis includes an examination of all the party's organizational components, such as the way they related to youth, the movement of the union, the newspapers' circulations, and the means by which they registered members. Also, there is an examination of the attempt to make the party global via its connections with communist centres like the Comintern. The author uses the last chapter to analyze the party's illegal period following the October 1931 crisis. The writer notes that the CPC, in order to be open to the whole population, acted as a union to allow an illegal party to emerge and then transformed itself into its successor, AKEL.

In his conclusions, which constitute the most critical portion of the book, the author argues that the CPC represented a political movement that espoused a particular program to radically reform colonial Cyprus, and that it was this foundation that signified a major change in the island's political life. It was able to penetrate into a large portion of society because of socio-economic conditions, with a particular emphasis on the population's lower classes, which they attempted to organize in order (as they saw it) to free them from being exploited by the church and the bourgeoisie. When the author introduces the CPC into this theoretical framework, he notes that the CPC could avoid intense divisions because the Church of Cyprus and the bourgeoisie were not distinctive. In addition, since neither the Church nor the upper classes were doing anything to improve the lower classes' living conditions, the CPC operated radically, and in an organized manner, to facilitate this. Thus the establishment of the CPC signalled a huge change in the political life of the island. It had long-term consequences for the internal balance of power within the Greek community, in particular, and within the political system more generally. These consequences were not initially apparent, but for the first time, a political force of the lower classes and the labouring poor challenged the dominant position of the bourgeois nationalist class and the Church, and claimed leadership of the anti-colonial struggle. It gave expression to the protest of marginalised social groups and classes, not as a form of simple resistance or an incidental revolt, but as a lasting political proposal. The CPC was an agent of action for social change, and at the political level expressed the radicalism of the popular strata.

The new reality the Party brought to the Cypriot political scene entailed the autonomous political and organisational presence of the Cypriot workers and peasants. CPC policies emphasised the satisfaction of social and economic needs, cooperation with the Turks of Cyprus, and a rejection of the nationalist rhetoric and ideas promoted by the bourgeois politicians and the Church. It marked the beginning of a rupture in the traditional mode of political organisation, which was previously a number of bourgeois groups, (most) guided by the Church, competing for power on the basis of political clientelism. Thus the establishment of the CPC placed Cypriot political life on new terms, and through its organisation and its political discourse, it challenged the religious domination of political life. The CPC aimed to reinforce its political and ideological singularity through its total rejection of the policy of enosis. The Party's political discourse was more dangerous for the pro-unionist politicians than for the colonial administration, at least until the late 1930s, because it threatened to upset the internal balance of power in the Greek community.

The author's study is based on considerable research into the state of a colonized space and how it developed on a global scale, which resulted in the CPC's founding. It is one of only a handful of studies that deal with Cyprus's history in this era and which historically analyze the situation from the perspective of the whole society. It is an original contribution, rich with theoretical insights and practical implications, and succeeds in providing a new approach for the study of Cyprus's political system. 
Source URL:https://reviews.history.ac.uk/review/1723

\section{Links}

[1] https://reviews.history.ac.uk/item/115729 